\title{
Evaluation of physical, chemical and heavy metal concentration of food waste composting.
}

\author{
Aeslina Abdul Kadir ${ }^{1,}$, Nur Wahidah Azhar $i^{2}$, and Siti Noratifah Jamaludin ${ }^{3}$ \\ ${ }^{1}$ Senior Lecturer, Department of Environmental Engineering and Water Resources, Universiti Tun \\ Hussein Onn Malaysia (UTHM) 86400 Parit Raja, Batu Pahat, Johor, Malaysia \\ 2,3 Department of Environmental Engineering and Water Resources, Universiti Tun Hussein Onn \\ Malaysia (UTHM) 86400 Parit Raja, Batu Pahat, Johor, Malaysia
}

\begin{abstract}
In this study, food waste composting with rice husk and coconut fibre as compost medium were carried out. Two types of different fermentation liquids were prepared which were fermented liquid (banana peel) and fermented liquid from fermented soybeans. During the composting process, a compost samples for a twenty week duration at an interval time of two weeks. Among the physico-chemical parameters that were tested were temperature, moisture content, $\mathrm{pH}$ value, Total Nitrogen, Total Phosphorous, Potassium and Total Organic Carbon and Carbon Nitrogen ratio. Heavy metals such as copper, cadmium, lead, nickel and arsenic were observed and analysed. From this study, it was found that, the temperature increased during the thermophilic phase while there was gradually increase of Total Nitrogen, Total Phosphorous and Potassium from the beginning till the end of the composting process. It was also found that the total organic carbon (TOC) and the carbon nitrogen ratio decreased significantly during the decomposition process. Traces amounts of heavy metals were also detected and remains below the standard Malaysian Environmental regulations. It was concluded that, the composting process was faster with processed food waste followed by combination of processed food waste and raw. Raw food waste were demonstrated the lowest degradation rate.
\end{abstract}

\section{Introduction}

Environmental Quality Act 1974 describe, waste included any matter prescribed to be scheduled waste or any matter, whether in a solid, semi-solid or liquid form or in the form of gas or vapour which is emitted, discharged or deposited in the environment in such volume, composition or manner as to cause pollution. This poor solid waste management lead to the environmental pollution such as leachate [1,2]. The challengers to overcome the municipal solid waste (MSW) generation are location and treatment of the waste. Landfill and open dumping is main disposal method practice in Malaysia. Landfilling of mixed waste is the worst solution of all as biological, chemical and physical degradation processes. Furthermore, the high amount of food waste in landfill contributes the foul odor,

* Corresponding author: aeslinaabdulkadir@gmail.com 
toxic leachate, emission of greenhouse gasses and vermin infestation [3]. In addition, according to Hesnawi and Mohamed [24] when food waste decomposes under the low oxygen conditions that are typically encountered in landfills, it produces methane, a harmful greenhouse gas that is twenty one times more contaminated than carbon dioxide, and it might contaminate groundwater

Therefore, composting is one of the potential waste management elements to divert organic waste generated to landfill [4]. The presence of a high percentage of biodegradable organic matter, acceptable moisture content and $\mathrm{C}: \mathrm{N}$ ratio in the waste and factors that influence the composting process [5]. Production of organic fertilizer from food wastes is an effective environmental sanitation and appropriate resource recovery strategy. Nutrient value of compost varies widely, depending upon the nature of feedstock composted [6].

\section{Materials and Method}

\subsection{Study area}

In this study, the waste was collected from small medium scale industry, Makanan Ringan Mas (MASi) at Parit Kuari Darat, Parit Raja, Johor. This industry waste mainly. mainly dominated by food waste. The food waste can be divided into two categories which are processed food waste and raw food waste. The processed food wastes consist of chips and candy, while the main raw food wastes that is generated are fruit peeling which are tapioca peel, banana peel and coconut husk. The average quantity of organic waste generated by this industry is in between $101.82 \mathrm{~kg} /$ month. The improper management of waste generated has been practiced and contributed to unhygienic conditions. Therefore, in this study, backyard composting food waste was carried out as alternatives to solid waste management due to its low cost and easy to operate

\subsubsection{Compost preparation}

In this study, two composting medium namely, rice husk and coconut fibre were mixed and prepared as the composting medium to compost of food waste (processed of food waste, raw of food waste and combination processed and raw of food waste). Composting was carried out at Micropollutant Research Centre (MPRC), UTHM. Two type of fermentation liquid was prepared which were fermented banana peel $\left(\mathrm{S}^{*}\right)$ and fermented soybeans $\left(\mathrm{C}^{*}\right)$ and eight reactors are prepared as in Table 1. Aeration of each reactors was accomplished through periodic turning at every 7-day. During composting process, the samples was collected through the degradation stages and placed into a close container. The samples were brought from week 1 to week 20 to the laboratory for physical-chemical characteristics and heavy metal concentrations.

\subsubsection{Physico-Chemical Analysis}

Temperature and moisture content value were monitored throughout the composting process. Temperature was measured by using thermometer whilst moisture content was conducted by using gravimetric method. Compost samples $(10 \mathrm{~g})$ was dried in an oven at $105{ }^{\circ} \mathrm{C}$ for $24 \mathrm{~h}$. Changes in $\mathrm{pH}$ was determined immediately after transportation into the laboratory and measured by using a ph meter using a method described by Dashan et al. [7] and was measured by $\mathrm{pH}$ meter. On the other hand, the total carbon was determined by Shimadzu SSM-5000 with TOC-Vcph analyzer by Method 5310 B.As for nutrient content, 
total nitrogen content was measured by Micro- Kjeldahl method, where available of total Phosphorous was extracted by digestion with nitric acid according to the method that was carried out by Webb and Adeloju [8]. Samples were analysed by Westco SmartChem 140 automated wet chemistry discrete analyser. As for potassium and heavy metal, the samples were extracted by nitric acid digestion according to Fanta \& Ade [9] and analysed by Atomic Absorption Spectrometer (AAS) and Inductively Coupled Plasma Mass Spectrometry (ICP-MS).

Table 1. Reactors prepared in the experiment work

\begin{tabular}{l|ll}
\hline \multicolumn{3}{c}{$\mathrm{C}^{*+}$ Rice Husk } \\
\hline C1 & : Control & $:-$ \\
C2 & : Processed food waste (Coconut Candy \& chips) & $: 250 \mathrm{~g}$ \\
C3 & : Raw food waste (Banana peel, tapioca peel \& grated coconut) & $: 250 \mathrm{~g}$ \\
C4 & : Processed and Raw food waste (Coconut Candy, chips, Banana peel, & $: 250 \mathrm{~g}$ \\
& tapioca peel \&grated coconut) & $:-$ \\
\hline \multicolumn{3}{c}{$\mathrm{S}^{*+}$ Coconut Fibre } \\
S1 & : Control & $: 250 \mathrm{~g}$ \\
S2 & : Processed food waste (Coconut Candy \& chips) & $: 250 \mathrm{~g}$ \\
S3 & : Raw Food waste (Banana peel, tapioca peel \& grated coconut) & $: 250 \mathrm{~g}$ \\
S4 & : Processed and Raw food waste (Coconut Candy, chips, Banana peel, & \\
\hline
\end{tabular}

\section{Result}

\subsection{Temperature}

In composting, heating is important. It is indicates that, microbial activity take place to degrade the organic matter [10]. According to Venglovsky et al. [11] it was suggested, that the microbial evaluation actually steadily and maximize around 35 and $40{ }^{\circ} \mathrm{C}$ during the composting process while according to Boulter et al. [12], when it reached 40 to $45^{\circ} \mathrm{C}$, it represent thermophilic phase. During thermophilic phase, the presence of weed seeds and pathogens in the compost are killed, due to hemicellulose and lignins was degraded.

In this study, these fluctuation of temperature reading, Fig. 1 may be explained by the differences of waste was placed into the reactor supported by Pagans et al. [13] where the combination of organic compounds. Which organic matter is mainly composed easily degradable and energetic compounds such as protein and fats and presents of large amount of organic nitrogen. At early early stage of composting the temperature is low due to less water content. It was slight increases in temperature after keep turning for aeration and after adding water. At the end of composting process, both treatments shows the temperatures tend to decrease where the compost was considered nearing mature phase. However, for reactor $\mathrm{C} 3$ and $\mathrm{S} 3$, both treatments had a quite low because the excess of moisture, cause slow the activity of microbial activity. The fluctuation of this temperature was same as previous studies by Abdul Kadir et al. [14], where it rise from the initial mesophilic phase to the thermophilic phase. 


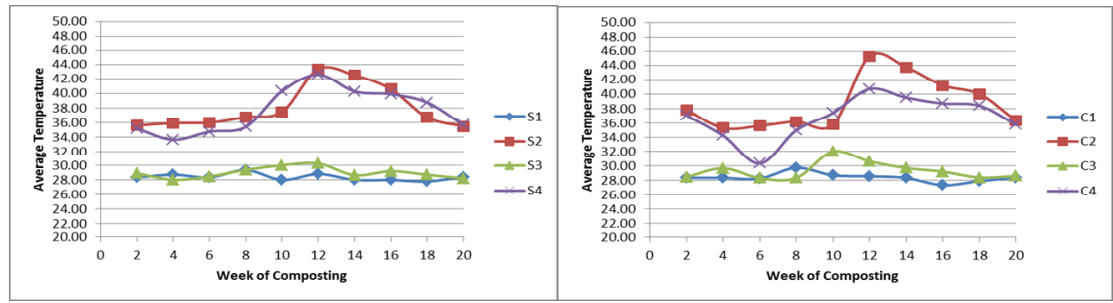

Fig. 1. Temperature by week in the reactor

\subsection{Moisture Content}

At the beginning, of the composting the moisture content for all reactors was low due to addition of food wastes, as shown in Fig. 2. In order to control the moisture content, water addiction was mad due to the moisture content of the food waste was low compare to the raw of food waste, before it was placed into each reactor. The waste was watered to ensure that the waste optimum moisture content was maintained in each reactor between 45-65\% moisture content were recorded. Middle of composting process, both composting medium, the moisture content was declined during week 5 and 6 for composting material reactor $\mathrm{C} 2, \mathrm{C} 3, \mathrm{~S} 2$ and S3.It may due to heat produces at thermophilic stage by actives of the microbial. It was supported by Shymala \& Belagali [15], that found the moisture content value were decreased during the composting period due to degradation of waste and heat generated by microbial activity.
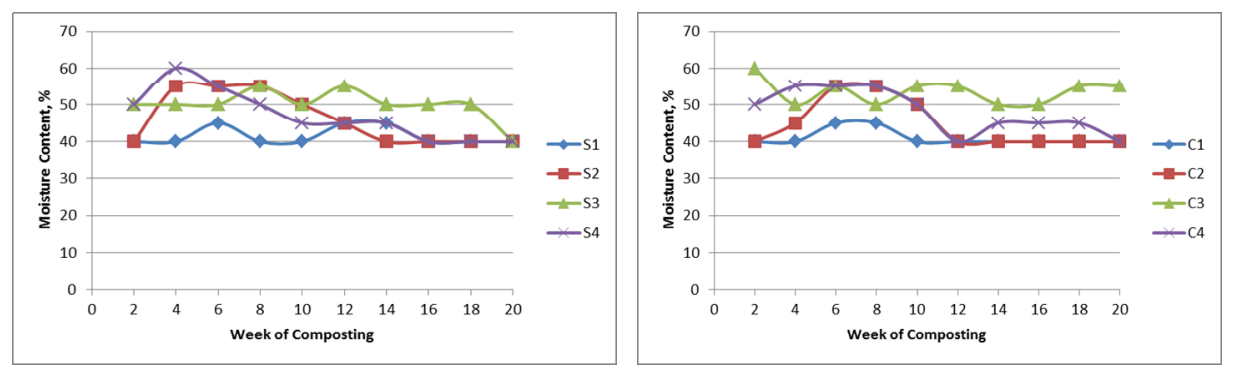

Fig. 2. Moisture content by week in the reactor

\section{$3.3 \mathrm{pH}$ value}

According to Arslan et al.[16], $\mathrm{pH}$ value was important in evaluating the microbial environment. This is also supported by Hubbe et al. [17] that, action of microbes can be found in the variation of $\mathrm{pH}$ during composting and the best for competent biological decomposition of organic waste also depend on $\mathrm{pH}$ [18]. The optimum $\mathrm{pH}$ for the degradation of organic waste in between of 6 to 7.5 [12,19]. Fig. 3 shows that, both treatments have similarity results which, were it acidic in early of composting. Then the $\mathrm{pH}$, increased to between 7 and 8 in the Week 3. The results indicates that the thermophilic phase has occurred and at the end of the composting the $\mathrm{pH}$ have been neutral. 


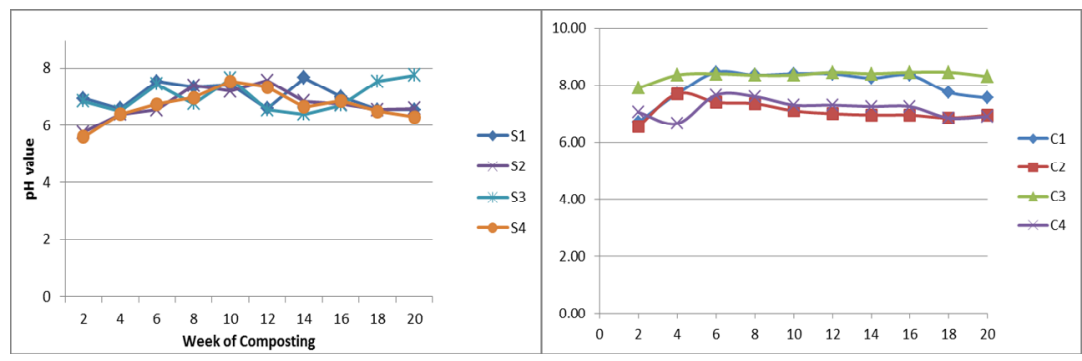

Fig. 3. $\mathrm{pH}$ value by week in the reactor

\subsection{Total Organic Carbon}

The amount of carbon found in an organic caompound is called total organic carbon. In this study, the graph shows that, decomposition of food waste by microorganisms during the composting period was decrease at the end of composting. The initial compost for C4 are $25.19 \%$ and $5.49 \%$ at end of composting. While for S4, the intial reading are $30.31 \%$ and decreased at the end of composting with $8.07 \%$. Total carbon concentration declined slightly for both compost as shown in Fig. 4. According to Jusoh et al. [20] carbon is sources of energy for microorganisms and transformed to carbon dioxide during metabolism process of the cells, while according to Ch'ing et al. [21], carbon was reduce at the end of composting due to active microbial cellulytic degradation and microbial proliferation which immobilize Nitrogen.

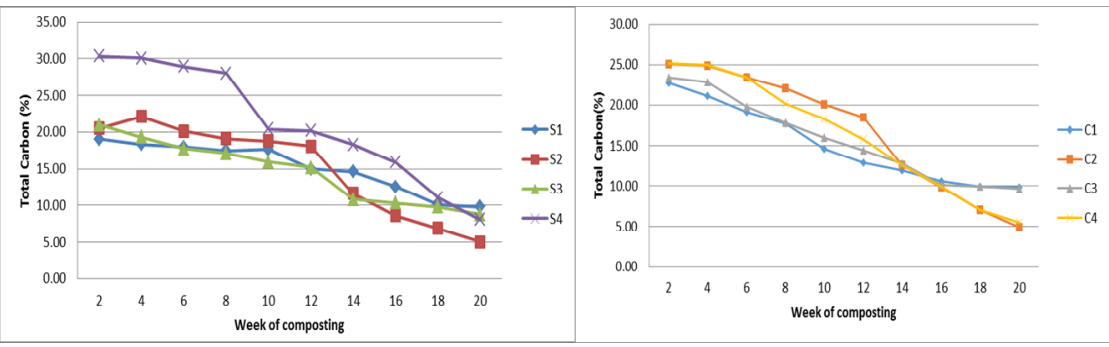

Fig. 4. Total Carbon by week in the reactor

\subsection{Total Nitrogen}

In this study, the concentration of total nitrogen all the reactors demonstrate increase value with composting time. As shown in Fig. 5, it was recorded that, $\mathrm{C} 2$ and $\mathrm{S} 2$ contain high $\mathrm{N}$ with $0.22 \%$ and $0.21 \%$ respectively. Compare with other previous researcher, concentration of total nitrogen, obtained is a quite low for this type of compost. This might due to ammonia volatilization and elevated temperature during composting process [22]. The concentration of total nitrogen, that retrieved from previous researchers varied from 1.00 to $2.45 \%$. In this study, lower total nitrogen was recorded, however the results are similar recorded by Gautam et al. [5] which is between 0.03 to $0.07 \%$. 


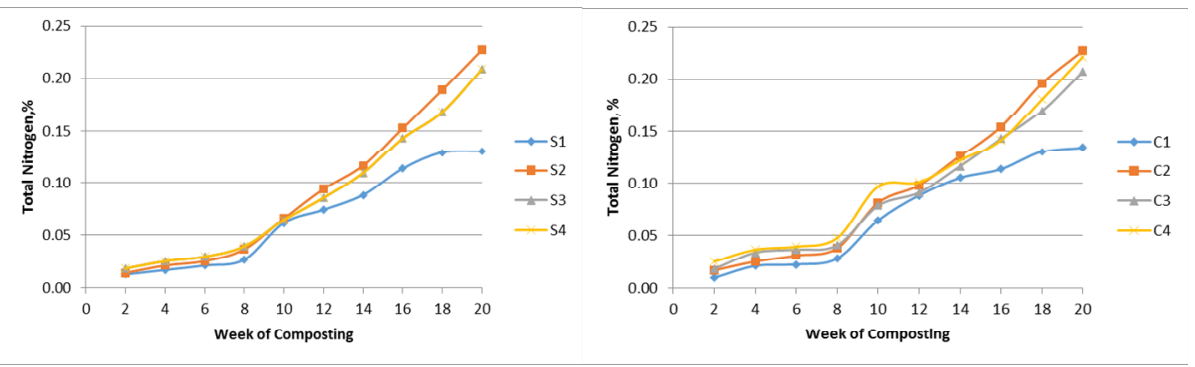

Fig. 5. Total Nitrogen by week in the reactor

\subsection{Total Phosphorous}

Fig. 6 shows values of phosphorous along 20 week of composting process. C4 (2.047 ppm to $11.615 \mathrm{ppm})$ and $\mathrm{S} 4(3.308 \mathrm{ppm}$ to $11.418 \mathrm{ppm})$ reactors demonstrated increment every week compare to reactor $\mathrm{C} 2, \mathrm{C} 3, \mathrm{~S} 2$ and $\mathrm{S} 3$. This is also discussed, the increase of phosphorous may be due to decreases of water solubility with humification so that phosphorous solubility during the decomposition was subjected to further immobilization factor $[23,15]$
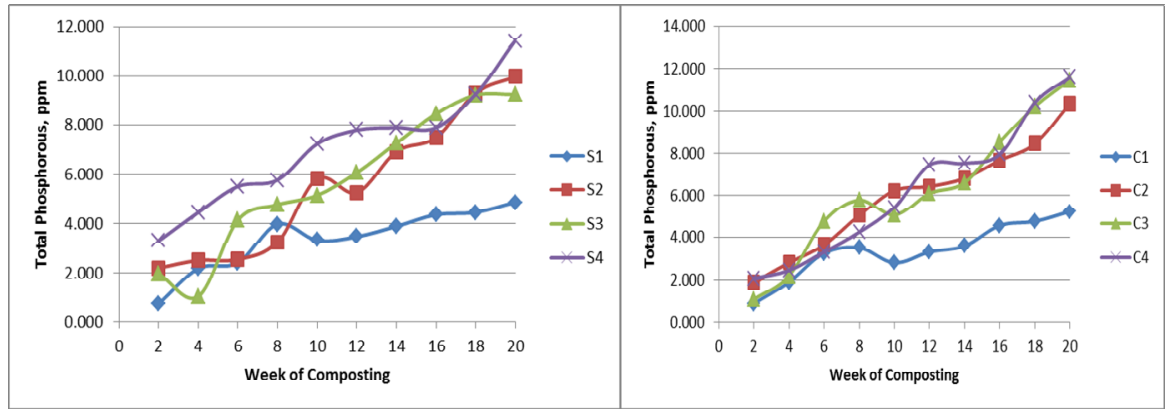

Fig. 6. Phosphorous versus week

\subsection{Potassium}

From Fig. 7, the values of potassium were observed increase at the end of composting process. At the end of the decomposition process, the value measured was obtained for reactors C2 $633.40 \mathrm{ppm}, \mathrm{S} 2666.95 \mathrm{ppm}, \mathrm{C} 3516.00 \mathrm{ppm}, \mathrm{S} 3582.21 \mathrm{ppm}, \mathrm{C} 4645.55 \mathrm{ppm}$ and S4 $606.65 \mathrm{ppm}$. Factors that contribute to increase the potassium value, are the decomposting medium used such as, coconut fibre and rice husk. Where this compost medium can absorb and maintain the moisture content. It supported by Syamala and Belagali [15] reported that, the raw material use is factor that influences of potassium increased, due to characteristics where allowed the absorption of moisture content and maintain structural integrity and porosity. 


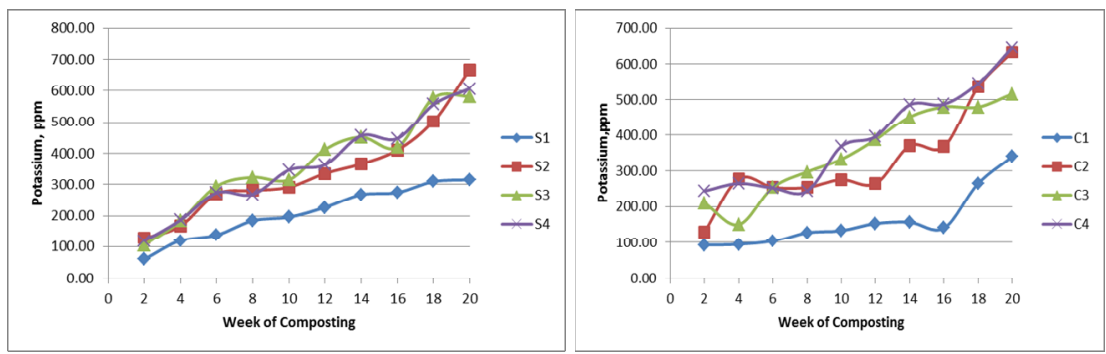

Fig. 7. Potassium versus week

\subsection{Heavy Metal}

Compost usually contains heavy metal based on their initial raw materials. In this study, heavy metals such as copper, cadmium, arsenic, nickel and lead concentration were measured in all reactor and compared to standard value retrieved from 9,26. Trace elements of heavy metal were found in all of the reactors as shown in Table 2 . The value is in accordance with the usage of a small amount of is essential for plant growth and vice versa.

Table 2. Average heavy metal concentration along composting process

\begin{tabular}{|c|c|c|c|c|c|c|c|c|c|}
\hline \multirow[b]{3}{*}{$\mathrm{Cu}$} & S1 & $C 1$ & $S 2$ & $C 2$ & S3 & C3 & S4 & C4 & \multirow{3}{*}{$\begin{array}{l}\text { Standard } \\
\text { Value } \\
(\mathrm{mg} / \mathrm{kg}) \\
1500^{\mathrm{a}, \mathrm{b}}\end{array}$} \\
\hline & \multicolumn{8}{|c|}{$(p p b)$} & \\
\hline & 167.86 & 133.48 & 172.57 & 187.75 & 190.59 & 206.2 & 182.87 & 193.08 & \\
\hline $\mathrm{Cd}$ & 3.58 & 3.26 & 3.73 & 2.39 & 2.59 & 3.32 & 3.96 & 3.25 & $35^{\mathrm{a},} 39^{\mathrm{b}}$ \\
\hline As & 144.31 & 138.96 & 123.35 & 122.83 & 154.24 & 139.2 & 141.1 & 141.83 & $41^{\mathrm{a}, \mathrm{b}}$ \\
\hline $\mathrm{Ni}$ & 91.3 & 140.11 & 117.4 & 152.54 & 106.51 & 117.79 & 113.65 & 140.08 & $420^{\mathrm{b}}$ \\
\hline $\mathrm{Pb}$ & 157.8 & 167.11 & 170.12 & 172.47 & 199.76 & 116.48 & 211.6 & 145.81 & $300^{\mathrm{a}, \mathrm{b}}$ \\
\hline
\end{tabular}

\section{$3.9 \mathrm{C} / \mathrm{N}$ ratio}

Fig. 8 shows the decrease in $\mathrm{C} / \mathrm{N}$ value in both treatments, it may be due to the mineralization of organic matter [20], on the other hand, according to Norbu [25] reduction in the $\mathrm{C} / \mathrm{N}$ ratio was due to the degradation of organic matter. In this study, it was slow of decrease in $\mathrm{C} / \mathrm{N}$ ratio. At week 10, both composting reactor $\mathrm{C} 2$ and $\mathrm{S} 2$ was 21.49 and 22.07 while the other reactor was between 25 to 45 . It can be concluded that, when food waste is fed into the reactor the $\mathrm{C} / \mathrm{N}$ slowly decrease. The degradation of waste is quite low. It can be compared with the control reactor. The $\mathrm{C} / \mathrm{N}$ ratio value can be faster decrease due to addition of sludge [25], otherwise many researchers reported that, by adding waste materials as animal waste, bagasse or garden waste can improved the $\mathrm{C} / \mathrm{N}$ ratio and enhance the decompose process. 


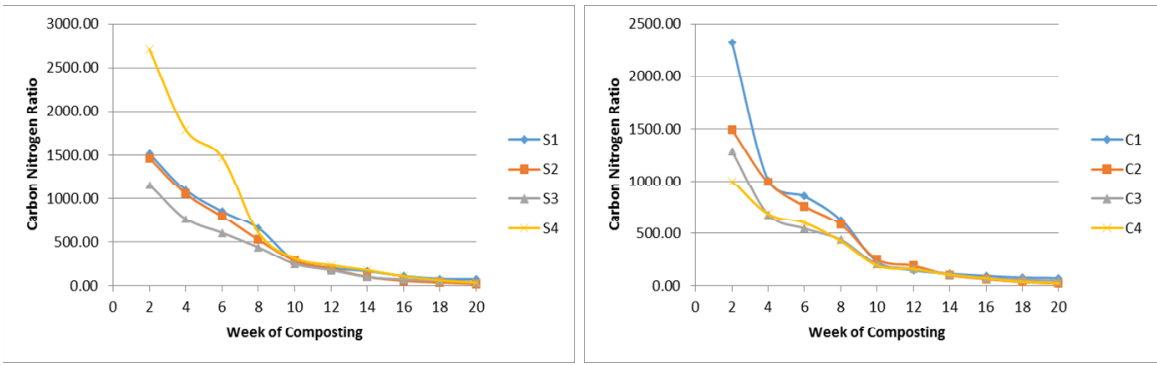

Fig. 8. Carbon Nitrogen ratio $(\mathrm{C} / \mathrm{N})$ value versus weeks

\section{Conclusion}

In this study, composting method was conducted as one of the feasible alternative method for reducing food waste generated at Makanan Ringan MAS. The results obtained proved that the composting method could produce acceptable value of nitrogen, phosphorous and potassium (NPK) and the heavy metal were also found to be in desirable limits. Therefore the organic compost produce could be used as fertilizers.

\section{References}

[1] S.N.S. Ismail and L.A. Manaf, The challenge of future landfill: A case study of Malaysia, J. of Toxicology and Environmental Health Sci., 5(6), 86-96, (2013)

[2] M.D.M. Samsudin, and M.M. Don, Municipal Solid Waste Management in Malaysia: Current Practices, Challenges and Prospect. J. Technology, 62(1), 95-101, (2013)

[3] A.A. Hamid, A. Ahmad, M.H. Ibrahim and N.N.N.A. Rahman, Food Waste Management in Malaysia- Current situation and future management options. J. of Industrial Research \& Tech., 2(1), 36-39, (2012)

[4] R. Hassan, F.A.A. Majid and A.A. Rahman, The Potential Of Implementing Food Waste Composting At Source Using Biosense Scheme. J. of Research in Applied Natural and Social Sciences, 3(4), 55-66, (2015)

[5] S. Gautam, P. Bundela, A. Pandey, M. Awasthi and S. Sarsaiya, Composting of municipal solid waste of Jabalpur city, Global J. of Env. Research, 4(1), 43-46, (2010)

[6] R.A.Z. Taleb, A.T. Rakad and R.A. Abdullah, Changes in Compost Physical and Chemical Properties during Aerobic Decomposition. Int. J. of Current Microbiology and Applied Sciences, 3(10), 479-486, (2014)

[7] H. Dahshan, A.M.M. Abd-Elall, M.A. Abd-El-Kader and A.M. Megahed, Field-scale management and evaluation of recycled cattle manure solids from livestock in Nile Delta ecosystem. African J. of Agricultural Research, 8(23), 2829-2836, (2013)

[8] B. Webb and S.B. Adeloju, Evaluation of some wet digestions methods for reliable determination of total phosphorus in Australian soils. Microchemical J. 111, 47-52 (2013)

[9] G.M. Fanta and A.G. Ede, Analyzing Selected Heavy Metals Content of Compost used in Ethiopia, Int. J. of Innovative and Applied Research, 2(9), 5-11, (2014)

[10]A. Hassen, K. Belguith, N. Jedidi, A. Cherif, M. Cherif and A. Boudabous, Microbial characterization during composting of municipal solid waste. Bioresource Technology, 80(3), 217-225, (2001) 
[11]J. Venglovsky, N. Sasakova, M. Vargova, Z. Pacajova, I. Placha, M. Petrovsky and D. Harichova, Evolution of temperature and chemical parameters during composting of the pig slurry solid fraction amended with natural zeolite. Bioresource technology, 96(2), 181-189, (2005)

[12]J. Boulter, G. Boland and J. Trevors, Compost: a study of the development process and end-product potential for suppression of turfgrass disease. World J. of Microbiology and Biotechnology, 16(2), 115-134, (2001)

[13]E. Pagans, R, Barrena, X. Font and A. Sánchez, Ammonia emissions from the composting of different organic wastes. Dependency on process temperature. Journal Chemosphere, 62(9), 1534-1542, (2006)

[14]A. Abdul Kadir, N. Rahman and N. Azhari, The Utilization of Banana Peel in the Fermentation Liquid in Food Waste Composting. IOP Conference Series: Materials Science and Engineering, 136(1), (2016)

[15]D.C. Shymala and S.L. Belagali, Studies on Variations in Physico-Chemical and Biological Characteristics at Different Maturity Stages of Municipal Solid Waste Compost. Int. J. of Environment Sciences, 2(4), 1984-1997, (2012)

[16]E.I. Arslan, A. Ünlü and M. Topal, Determination of the effect of aeration rate on composting of vegetable-fruit wastes. CLEAN-Soil, Air, Water, 39(11), 1014-1021, (2001)

[15]M.A. Hubbe, M. Nazhad and C. Sánchez, Composting as a way to convert cellulosic biomass and organic waste into high-value soil amendments: A review. BioResources, 5(4), 2808-2854, (2010)

[16]K. Atalia, D. Buha, K. Bhavsar and N. Shah, A Review on Composting of Municipal Solid Waste. IOSR J. of Environmental Science, Toxicology and Food Technology (IOSR-JESTFT), 2319-2402, (2015)

[17]M. Gómez-Brandón, C. Lazcano and J. Domínguez, The evaluation of stability and maturity during the composting of cattle manure. Chemosphere, 70(3), 436-444, (2008)

[18] M.L.C. Jusoh, L.A. Manaf, and P.A. Latiff, Composting of rice straw with effective microorganisms (EM) and its influence on compost quality. Iranian J. of Env. Health Science \& Engineering, 10(1), (2013)

[19]H.Y. Ch'ng, O.H. Ahmed, S. Kassim and N.M.A. Majid, Co-composting of pineapple leaves and chicken manure slurry. Int. J. of Recycling of Organic Waste in Agriculture, 2(1), 1-8, (2013)

[20]G. Civeira, Influence of municipal solid waste compost on soil properties and plant reestablishment in peri-urban environments, (2011)

[21]T. Janakiram and K. Sridevi, Conversion of waste into wealth: A study in solid waste management. J. of Chemistry, 7(4), 1340-1345, (2010)

[22] J.E. Montoya, T.M. Waliczek and M.L. Abbott, Large scale composting as a means of managing water hyacinth (Eichhornia crassipes). Invasive Plant Science and Management, 6(2), 243-249, (2013)

[23]T. Norbu, Pretreatment of municipal solid waste by windrow composting and vermicomposting, A thesis for the degree of Master of Science, 1-103, (2002)

[24] Hesnawi, R. M., and Mohamed, R. A, Effect of organic waste source on methane production during thermophilic digestion process. Int. J. of Environmental Science and Development, 4(4), 435. (2013) 